\title{
Estimate Level of Radon Concentration for Drinking Water in Some Regions of Baghdad City
}

\author{
Basim Khalaf Rejah ${ }^{1} \cdot$ Nisreen Khalil Abd Alameer ${ }^{1}$. Weaam Hasan Kadim ${ }^{1} \cdot$ Sara Talal Mohammed Murad ${ }^{1}$
}

Received: 7 November 2016 / Accepted: 4 January 2018 / Published online: 12 March 2018

(c) The Author(s) 2018

\begin{abstract}
In this study, the assessment of radon concentration in drinking water in some regions of Baghdad city in Iraq has been studied using CR-39 solid-state nuclear track detector technique. A total of 18 samples selected from 6 region (5 samples from each region) in Baghdad city have been placed in the dosimeters for 50 day. The average radon concentration was found to be $516.1 \mathrm{~Bq} / \mathrm{m}^{3}$ which is greater than the standard international limit $\left(300 \mathrm{~Bq} / \mathrm{m}^{3}\right)$. The potential alpha energy concentration and annual effective dose have been calculated. A proportional relationship between the annual effective dose and radon concentration within the studied region has been certified.
\end{abstract}

Keywords Radon gas $\cdot$ CR-39 detector - Drinking water - Annual effective dose

\section{Introduction}

Radon 222 is one of the periodic table elements located within the range noble elements (noble gases) (helium-neonxenon, etc.); a gas is invisible and tasteless and odorless, and this component is generated within the intermediate stage of decomposition uranium- 238 which includes the addition of radon generating several other radioactive elements, ending a series decays this element lead [1], where $\alpha$ is the gross alpha:

${ }^{226} \mathrm{Ra} \stackrel{\alpha}{\longrightarrow}{ }^{222} \mathrm{Rn} \stackrel{\alpha}{\longrightarrow}{ }^{218} \mathrm{Po} \stackrel{\alpha}{\longrightarrow}{ }^{214} \mathrm{~Pb}$

Is an inert gas with an atomic number of 86 , the most stable mass number is 222 , its density is $9.7 \mathrm{~kg} / \mathrm{m}^{3}$, its boiling point is $-61.8^{\circ} \mathrm{C}$, the melting point is $-71^{\circ} \mathrm{C}$ [2]. It is seven times heavier than air, and is continuously present in all places [3].

The radon-222 natural nuclear radiation is mainly generated by the natural decay of a series of uranium sources ${ }^{238} \mathrm{U}$, thorium ${ }^{232} \mathrm{Th}$ and uranium ${ }^{235} \mathrm{U} .{ }^{222} \mathrm{Rn}$ is the only metal which is in a gaseous state [4]. Radon have three radioactive isotopes: radon ${ }^{222} \mathrm{Rn}$, thoron ${ }^{220} \mathrm{Rn}$ and actinon

${ }^{219} \mathrm{Rn}$. In geological and environmental studies, the counter-

Basim Khalaf Rejah

dr.basim2014@gmail.com

1 College of Science for Women, Baghdad University, Baghdad, Iraq part ${ }^{222} \mathrm{Rn}$ was recognized relatively long for the half-life 3.82 day while can neglect the other isotopes ${ }^{220} \mathrm{Rn}$ and ${ }^{219} \mathrm{Rn}$ due to the short half-life 5.66 and $3.92 \mathrm{~s}$ respectively [4]. The US Environmental Protection Agency EPA has proposed the maximum concentration of radon in drinking water in $1100 \mathrm{~Bq} / \mathrm{m}^{3}$ [5].

The radon leads to health risks via two paths that are inhaled radon and products decay after liberation from the water to the air of homes and direct ingestion of radon in drinking water, the risk of lung cancer resulting from inhalation of decay products of radon; the radon gas was not linked to any other more disease of cancer, and the risk of inhalation may exceed far beyond the ingestion [6].

The collision of alpha particles that emits from the radon decay with the atoms and molecules that make up the tissues and organs of the body, produces chemical effects and major disturbances. The average length of the path of alpha particles in soft tissue is about $40 \mu \mathrm{m}$. The capacity of ionizing increases by more than 1000 times the energy beta particles and thus be more destructive to human tissue, hence the exposure to radon decay products of ${ }^{222} \mathrm{Rn}$ and risks $[7,8]$. In addition to what the offer is part of the annual effective equivalent dose to people in WHO's (The World Health Organization) estimated up to $2 \mathrm{mSv} / \mathrm{year}$ with radioactive background unusual environment comes from human inhalation of radon ${ }^{222} \mathrm{Rn}$ at a rate of $0.8 \mathrm{mSv} /$ year [9].

The current research aims to measure and study the radon concentration in the drinking water for drinking in differ- 
ent regions of the city of Baghdad: Amil district, Aljamaa district, Almwasalat district, Palestine street, Alkharijeaa district and Shuhada district (as shown in the following table) to be noticed to radon as a source of danger to people's health because of the breadth it spreads in the soil, building materials and groundwater, as well as not without water removing water networks in some areas of this gas.

Coordinates of sampling sites (GPS).

\begin{tabular}{llll}
\hline Site & N & E & $\begin{array}{l}\text { Height } \\
\text { above sea } \\
\text { level (m) }\end{array}$ \\
\hline Amil district & $33^{\circ} 33^{\prime} 38^{\prime \prime}$ & $44^{\circ} 27^{\prime} 39^{\prime \prime}$ & 36 \\
Aljamaa district & $33^{\circ} 46^{\prime} 01^{\prime \prime}$ & $44^{\circ} 13^{\prime} 05^{\prime \prime}$ & 38 \\
Alkharijeaa district & $33^{\circ} 37^{\prime} 32^{\prime \prime}$ & $44^{\circ} 15^{\prime} 26^{\prime \prime}$ & 37 \\
Almwasalat district & $33^{\circ} 23^{\prime} 44^{\prime \prime}$ & $44^{\circ} 91^{\prime} 20^{\prime \prime}$ & 37 \\
Shuhada district & $33^{\circ} 11^{\prime} 52^{\prime \prime}$ & $44^{\circ} 63^{\prime} 32^{\prime \prime}$ & 33 \\
Palestine street district & $33^{\circ} 03^{\prime} 47^{\prime \prime}$ & $44^{\circ} 53^{\prime} 52^{\prime \prime}$ & 38 \\
\hline
\end{tabular}

\section{Measurement Methods}

Five bottles of half a liter of water were taken from the water distribution system in the studied area. The samples were placed in can technique with CR-39-type track detectors with $200 \mu \mathrm{m}$ thickness and dimensions of $1 \mathrm{~cm} \times 1 \mathrm{~cm}$. Dosimeters are shown in Fig. 1 after an exposure time of 50 days; the dosimeters were collected and chemically etched $\left(6.25 \mathrm{~N} \mathrm{NaOH}\right.$ at $80^{\circ} \mathrm{C}$ over $4 \mathrm{~h}$ period) [10]. To account the number of tracks $/ \mathrm{cm}^{2}$ occurred in each detector, an optical microscope with a magnification of $40 \times$ was used with CCD camera (charge coupled device) Fig. 2.

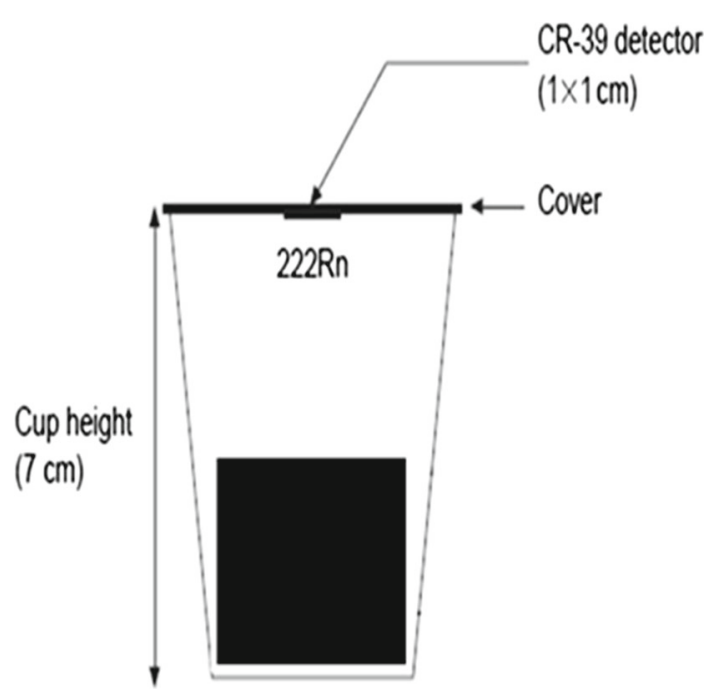

Fig. 1 Schematic diagram showing the geometry of radon dosimeter used in the study

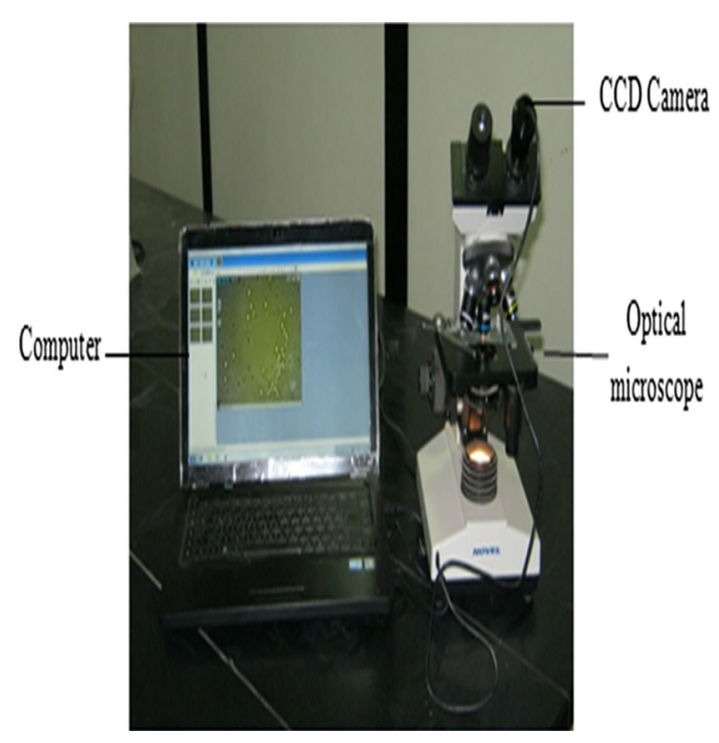

Fig. 2 The track counting system

\section{Calculations and Evaluations}

The CR-39 detectors exposed to the samples will be affected by radon and its daughters in the volume of air around them. In relating the observed track densities to the radon and its daughter activities per unit volume of air, the following equation has been used [11].

$\rho=x A$

where $\rho$ is the number of tracks per $\mathrm{cm}^{3}, x$ is a constant with dimension of length $(\mathrm{cm} / \mathrm{Bq}), A$ is the alpha activity per unit volume (disintegrations per unit time per $\mathrm{cm}^{2}$ ).

The value of the constant $x$ is the sum of separate constants calculated for all isotopes $\left({ }^{222} \mathrm{Rn},{ }^{218} \mathrm{Po}\right.$ and $\left.{ }^{214} \mathrm{Po}\right)$. In order to estimate the radon concentration, experimental method for radon detection and measurement are based on alpha-counting of radon and its daughters. The track density was calculated in terms of number of tracks $/ \mathrm{mm}^{2}$; the average number of tracks was determined by processing an unexposed films CR-39 detector under identical etching condition. The signal measured by etched track detectors is integrated track density, $\rho$ (track $/ \mathrm{mm}^{2}$ ) recorded on the detector, $K_{i}(0.004)$ the average value of the calibration factor of ${ }^{222} \mathrm{Rn}$ in $\left(\mathrm{Bq}\right.$ day $\left.\mathrm{m}^{-3}\right)$ per (tracks $\left./ \mathrm{mm}^{2}\right)$ and $T$ exposure time (50 day) has been applied to determine the activity of ${ }^{222} \mathrm{Rn}$ concentration $\left(C_{\mathrm{Rn}}\right)$ in $\mathrm{Bq} / \mathrm{m}^{3}$ using the following equation [12]:

$C_{\mathrm{Rn}}=\frac{\rho}{T K_{i}}$ 
Table 1 Radon concentration, CEEC, WL, Eff, ECR, excess lung cancer per million person per year and $E_{\mathrm{x}}$ rate for water samples

\begin{tabular}{|c|c|c|c|c|c|c|c|c|c|c|}
\hline Sample & $\begin{array}{l}\text { Track } \\
\text { average }\end{array}$ & $\begin{array}{l}\text { Density } \\
\left(\text { track } / \mathrm{cm}^{2}\right)\end{array}$ & $\begin{array}{l}C_{\mathrm{Rn}} \\
\left(\mathrm{Bq} / \mathrm{m}^{3}\right)\end{array}$ & $F$ & $\begin{array}{l}\text { CEEC } \\
\left(\mathrm{Bq} / \mathrm{m}^{3}\right)\end{array}$ & WL & $\begin{array}{l}\text { Eff. } \\
\text { (mSv/year) }\end{array}$ & ECR & $\begin{array}{l}\text { Excess lung } \\
\text { cancer per } \\
\text { million } \\
\text { persons per } \\
\text { year }\end{array}$ & $\begin{array}{l}E_{\mathrm{x}} \text { rate } \\
\left(\mathrm{Bq} / \mathrm{m}^{2} \mathrm{~h}\right)\end{array}$ \\
\hline Amil district & 122 & 67.8 & 336 & 0.4 & 134.4 & 0.036 & 8.48 & 0.005 & 5000 & 0.038 \\
\hline Aljamaa district & 260 & 144.4 & 716.3 & 0.4 & 286.5 & 0.077 & 18.07 & 0.01 & 10,000 & 0.08 \\
\hline Almwasalat district & 112 & 62.2 & 308.5 & 0.4 & 123.4 & 0.033 & 7.78 & 0.0047 & 4700 & 0.035 \\
\hline Palestine street & 130 & 72.2 & 358.1 & 0.4 & 143.3 & 0.039 & 9.035 & 0.0054 & 5400 & 0.04 \\
\hline AlKharijeaa district & 180 & 100 & 495.9 & 0.4 & 198.4 & 0.054 & 12.51 & 0.0075 & 7500 & 0.06 \\
\hline Shuhada district & 320 & 178 & 881.6 & 0.4 & 352.6 & 0.095 & 22.24 & 0.0133 & 13,300 & 0.1 \\
\hline Average & 187.3 & 104.1 & 516.1 & & 206.4 & 0.056 & 13.02 & 0.008 & 7650 & 0.058 \\
\hline
\end{tabular}

Almost all measurements of radon levels in the home or outdoors are expressed as the concentration of radon in units of picocuries per liter of air ( $\mathrm{pCi} / \mathrm{liter}$ ), or in SI units as Becquerel per cubic meter $\left(\mathrm{Bq} / \mathrm{m}^{3}\right)$, or radon daughters are expressed in working levels (WL), which is given by [13]:

$C_{\mathrm{p}}(\mathrm{WL})=\frac{F * C_{\mathrm{Rn}}}{3700}$

where $F$ is the equilibrium factor and recommended as $F C_{\mathrm{Rn}}=0.4$ [14].

Therefore, the relation between the effective dose and Radon concentration is given by:

Eff. $=G C_{\mathrm{Rn}}$

where $G$ is a constant 0.4 (conversion factor).

In this study measurement of indoor radon concentration $\left(C_{\mathrm{Rn}}\right)$, potential alpha energy concentration (PAEC) and annual effective dose (Eff.) has been taken. The potential alpha energy concentration (WL) was calculated using Eq. (3); annual effective dose equivalent has been calculated using Eq. (4). Exhalation rate was also calculated using the following equation [11]:

$E_{\mathrm{x}}=\frac{C_{t} \lambda V}{S\left[t-1 / \lambda\left(1-e^{-\lambda T}\right)\right]}$

where $E_{\mathrm{x}}$ is radon exhalation rate $\left(\mathrm{mBq} / \mathrm{m}^{2} \mathrm{~h}\right), C_{\mathrm{t}}$ is mean radon concentration as measured by $\mathrm{CR}-39$ detector $\left(\mathrm{Bq} / \mathrm{m}^{3}\right)$, $V$ is volume of the can $\left(\mathrm{m}^{3}\right), t$ is the exposure time, $\lambda$ is the radon decay constant and $S$ is the surface area from which radon is exhaled into the closed can.

\section{Results and Discussion}

The overall results for radon concentrations in $\mathrm{Bq} / \mathrm{m}^{3}$, radon exhalation rates in $\mathrm{Bq} / \mathrm{m}^{2} \mathrm{~h}$, the equilibrium equivalent ${ }^{222} \mathrm{Rn}$ concentration (CEEC in $\mathrm{Bq} / \mathrm{m}^{3}$ ), and the annual effective dose $E_{\mathrm{ff}}$ (in $\mathrm{mSv} /$ year) for six drinking water samples from six region in Baghdad city are given in Table 1 . The water samples were taken from the water pipes that reach the houses. $100 \mathrm{ml}$ from each type of water was taken was put in a plastic cup, and then the plastic detector (CR-39) was fixed in the bottom of the cover $5 \mathrm{~cm}$ above the surface of the sample as shown in Fig. 1; three samples for each type of water were used, and the average was taken.

The overall average value of the activity concentrations of ${ }^{222} \mathrm{Rn}$ for drinking water samples was $516.1 \mathrm{~Bq} / \mathrm{m}^{3}$. The maximum concentration of ${ }^{222} \mathrm{Rn}$ was $881.6 \mathrm{~Bq} / \mathrm{m}^{3}$ appeared in Shuhada district sample, and the minimum concentration was $308.5 \mathrm{~Bq} / \mathrm{m}^{3}$ in Almwasalat district sample. The calculated CEEC values showed that the maximum value was $352.6 \mathrm{~Bq} / \mathrm{m}^{3}$ in Shuhada district sample, and the minimum value was $123.4 \mathrm{~Bq} / \mathrm{m}^{3}$ in Almwasalat district sample. The overall average value of CEEC for ${ }^{222} \mathrm{Rn}$ was $206.4 \mathrm{~Bq} / \mathrm{m}^{3}$, and this showed that the concentration of radon emitted from the samples does not depend on ${ }^{226} \mathrm{Ra}$ concentration only. The overall average value of the annual effective dose $\mathrm{E}_{\mathrm{ff}}$. obtained for drinking water samples set was $13.02 \mathrm{mSv} / \mathrm{year}$, while the maximum value was $22.24 \mathrm{mSv} / \mathrm{year}$ in Shuhada district sample, and the minimum value was $7.78 \mathrm{mSv} /$ year in Almwasalat district sample. Figure 3 shows the relationships between $\mathrm{E}_{\mathrm{ff}}$. in $\mathrm{mSv} / \mathrm{year}$ and radon concentration $\mathrm{Bq} / \mathrm{kg}$. From this figure, one can note that the relationships are linearly increasing, and useful fitting equations can be deduced;

Eff. $=0.0252 * C_{\mathrm{Rn}}\left(\mathrm{Bq} / \mathrm{m}^{3}\right)$

The overall average value of excess lung cancer per million persons per year (ELC) for the full drinking water samples set 


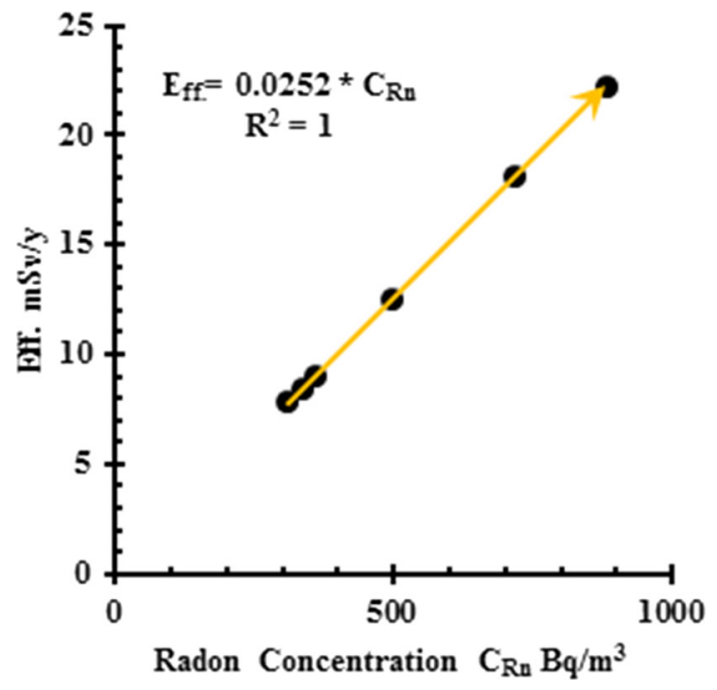

Fig. 3 Eff. as a function of radon concentration $\mathrm{Bq} / \mathrm{m}^{3}$

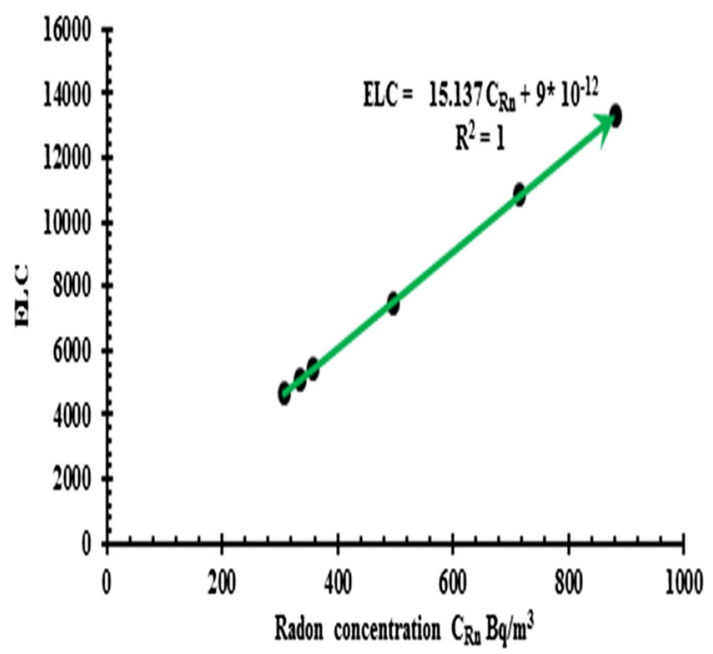

Fig. 4 The relation between ELC and radon concentration $C_{\mathrm{Rn}}\left(\mathrm{Bq} / \mathrm{m}^{3}\right)$

was 7650. The highest value was 13,300 in Shuhada district sample, and the minimum value was 4700 in Almwasalat district sample. Additionally, this disparity in the values is due to differences of the nature of drinking water samples. Figure 4 shows the relationship between ECL and radon concentration $\mathrm{Bq} / \mathrm{m}^{3}$. From this figure, the fallowing equation is good fitting equation:

$\mathrm{ELC}=15.137 C_{\mathrm{Rn}}\left(\mathrm{Bq} / \mathrm{m}^{3}\right)+9 * 10^{-12}$

These sites were randomly selected and represent areas with moderate population density. Most of the population receives drinking water at a rate of 21 per day from the water distribution network in Baghdad governorate.

This study is part of a series of environmental assessment studies in Baghdad Governorate [2,16,17].

\section{Conclusions}

The radon concentration values obtained was varied within the studied drinking water samples in different region in Baghdad city. The recorded values of radon concentration were greater than these values in Wassit governorate $(0.82 \mathrm{~Bq} / \mathrm{L})[15]$, greater than their values in the University of Baghdad, Jadiriyah site $46.227 \mathrm{~Bq} / \mathrm{m}^{3}$ [16] and greater than the standard limits. A linear relationship has been traced between the annual effective dose and the measured radon concentrations.

Open Access This article is distributed under the terms of the Creative Commons Attribution 4.0 International License (http://creativecomm ons.org/licenses/by/4.0/), which permits unrestricted use, distribution, and reproduction in any medium, provided you give appropriate credit to the original author(s) and the source, provide a link to the Creative Commons license, and indicate if changes were made.

\section{References}

1. Reid, J.M.: The Atomic Nucleus, 2nd edn. Manchester University Press, Manchester (1986)

2. Shafik, S.S.; Rejah, B.K.: Measurement of the uranium concentration in different types of tea used in Iraqi kitchen. Iraqi J. Sci. 55(3A), 1039-1043 (2014)

3. Al-Ani, N.H.K.; Tawfiq, N.F.; Ghayb, D.H.: Measurement of alpha emitter's concentration in tomato fruits using CR-39 plastic track detector. Baghdad Sci. J. 7(1), 31-35 (2010)

4. Shafik, S.S.; Rejah, B.K.; Ameer, A.H.A.: Radon concentration measurements in sludge of oil fields in North Oil Company (N.O.C.) of Iraq. Iraqi J. Phys. 13(26), 139-145 (2015)

5. EPA: Edition of the Drinking Water Standards and Health Advisories. EPA 822-S-12-001, Washington DC (2012)

6. Semat, H.; Albright, J.R.: Introduction to Atomic and Nuclear Physics, 5th edn. Holt, Rinehart and Winston, Inc., New York (1972)

7. Idriss, H.; Salih, I.; Sam, A.K.: Study of radon in ground water and physicochemical parameters in Khartoum state. J. Radiat. Nucl. Chem. 290, 333-338 (2011)

8. Sharma, N.R.; Virk, H.S.: Environmental radioactivity: a case study of Punjab, India. Adv. Appl. Sci. Res. 2, 186-190 (2011)

9. WHO, UNICEF Improved and unimproved water sources and sanitation facilities. In: Geneva: WHO/UNIFEC Joint Monitoring Programme (JMP) for Water Supply and Sanitation. http://www. wssinfo.org/definitions-methods/watsan-categories/. Accessed 30 Nov 2015 (2016)

10. Salman, T.M.: The effect of stirring and interruption on the etching characteristic of CR-39 track detector. J. Basrah Res. 36(3), 17-21 (2010)

11. Abu-Jarad, F.; Fremlin, J.H.: A study of radon emitted from building materials using plastic alpha-track detectors. Phys. Med. Biol. 25, 683-694 (1980)

12. Tawfiq, N.F.; Nasir, H.M.; Khalid, R.: Determination of radon concentrations in AL-NAJAF governorate by using nuclear track detector CR-39. J. Al-Nahrain Univ. 15(1), 83-87 (2012)

13. Khan, A.J.; Varhney, A.K.; Prasad, R.; Tyagi, R.K.; Ramachandran, T.V.: Calibration of a CR-39 plastic track detector for the measurement of radon and its daughters in dwellings. Nucl. Tracks. Radiat. Meas. 17, 497-502 (1990) 
14. UNSCEAR (United National Scientific Committee on the Effects of Atomic Radiation). Report to the General Assembly, United Nations, New York (2010)

15. Najam, L.A.; Karim, M.S.; Hameed, T.K.: Measurement of radon gas concentration in tap water samples in Wassit governorate by using nuclear track detector (CR-39). Int. J. Phys. 4(5), 119-122 (2016)
16. Shafik, S.S.; Mohammed, A.A.: Measurement of radon and uranium concentrations and background gamma rays at the University of Baghdad-Jadiriyah site. Int. J. Appl. Innov. Eng. Manag. 2(5), 455-462 (2013)

17. Rejah, B.K.; Ashoor, G.T.: Radon gas concentration measurement in air of Al-Haswaa City in Province of Baghdad. Iraqi J. Sci. 58(2A), 663-668 (2017) 